\title{
PELAKSANAAN PENGELOLAAN KEUANGAN DESA SETELAH BERLAKUNYA UNDANG-UNDANG NOMOR 6 TAHUN 2014 TENTANG DESA (STUDI DI KABUPATEN DOMPU)
}

\author{
MANAGEMENT IMPLEMENTATIONOF VILLAGEFINANCE AFTER \\ LAW NUMBER 6 YEAR 2014 ON VILLAGE (STUDY IN DOMPU \\ DISTRICT)
}

\author{
Sahrul Haidin \\ Magister Ilmu Hukum Universitas Mataram \\ Email : sahrulhaidin5@gmail.com
}

Naskah diterima : 21/03/2017; revisi : 25/03/2017; disetujui : 27/04/2017

\begin{abstract}
This research aims are to know arrangement, effort and reinforcement of monetary management of Countryside after going into effect /Law Number 6 year 2014 on Village. This Research focus at three problems. This Research type is normative-empiric with legislation, conceptual and sociological approaches. Regulation of village financial management regulated in Law Number 6 year 2014 on Village, Government Regulation Number 47 year 2015 on implementing regulation of Law Number 6 year 2014 on Village, Minister Regulation Number 5 year 2015 on utilization Determination of Village Funds and Regulation of Minister of Domestic Affairs Republic of Indonesia Number 113 Year 2014 on Village Funding Management, receipt standard for purchasing of service and goods is not available yet. Obstacle of village finance management after the entry into force of Law on Village is the unreasoned of human resource and institution and regulation aspect and, managerial aspect.. While efforts to strengthen the implementation of financial management to improve the village head knowledge as a guarantor of good financial management and streamline village assistance.
\end{abstract}

Keyword: Execution Of Management of Finance Countryside

ABSTRAK

Peneltian ini bertujuan mengetahui pengaturan, hambatan dan upaya penguatan pengelolaan keuangan Desa setelah berlakunya Undang-Undang No 6 tahun 2014 tentang Desa. Penelitian ini berfokus pada ketiga masalah tersebut. Jenis penelitiannya adalah penelitian hukum normatif dan empiris dengan pendekatan perundang-undangan, konseptual dan sosiologis. Pengaturan pengelolaan keuangan desa terdapat dalam Undang-Undang Nomor 6 tahun 2014 tentang Desa, Peraturan Pemerintah No 47 tahun 2015 tentang peraturan pelaksana Undang-Undang No 6 tahun 2014 tentang Desa, Peraturan Menteri Desa, Pembangunan Daerah Tertinggal, dan Transmigrasi Nomor 5 tahun 2015 Tentang Penetapan Prioritas Penggunaan dana Desa dan Peraturan Menteri Dalam Negeri Republik Indonesia Nomor 113 Tahun 2014 Tentang Pengelolaan Keuangan Desa, belum tersedianya standar kwitansi pembelian barang dan jasa untuk Desa. Hambatan pengelolaan keuangan desa setelah berlakunya undang-undang Desa adalah tidak adanya kesiapan sumber daya manusia dan aspek regulasi dan lembaga, aspek tata laksana, kurangnya pengawasan. Sedangkan upaya penguatan pelaksanaan pengelolaan keuangan desa meningkatkan pengetahuan kepala desa sebagai penjamin pengelolaan keuangan desa yang baik dan mengefektifkan pendampingan Desa.

Kata Kunci : Pelaksanaan Pengelolaan Keuangan Desa 


\section{PENDAHULUAN}

Pemerintah Desa dalam melaksanakan kewenangan pengelolaan keuangan Desa tidak lain untuk meningkatkan pembangunan menuju masyarakat yang adil, makmur, dan sejahtera. Hal ini dapat ditelusuri dari teks hukum Undang-Undang No. 6 Tahun 2014 tentang Desa pada pasal 1 ayat 1 memberikan batasan tentang Desa. Desa adalah desa dan desa adat atau yang disebut dengan nama lain, selanjutnya disebut Desa, adalah kesatuan masyarakat hukum yang memiliki batas wilayah yang berwenang untuk mengatur dan mengurus urusan pemerintahan, kepentingan masyarakat setempat berdasarkan prakarsa masyarakat, hak asal usul, dan atau hak tradisional yang diakui dan dihormati dalam sistem pemerintahan Negara Kesatuan Republik Indonesia. ${ }^{1}$

Pasal 1 ayat 2 UU No. 6 Tahun 2014 tentang Desa, pemerintahan Desa adalah penyelenggaraan urusan pemerintahan dan kepentingan masyarakat setempat dalam sistem pemerintahan Negara Kesatuan Republik Indonesia. ${ }^{2}$ Pasal 1 ayat 3 yang menyatakan, bahwa Pemerintah Desa adalah Kepala Desa atau yang disebut dengan nama lain dibantu perangkat Desa sebagai unsur penyelenggara Pemerintahan Desa. ${ }^{3}$ Pasal 1 angka 4 yang dimaksudkan unsur lain, yakni Badan Permusyawaratan Desa atau yang disebut dengan nama lain adalah lembaga yang melaksanakan fungsi pemerintahan yang anggotanya merupakan wakil dari penduduk Desa berdasarkan keterwakilan wilayah dan ditetapkan secara demokratis. $^{4}$

Berkaitan dengan kewenangan pengelolaan dana Desa di atur dalam Undang Undang Nomor 6 Tahun 2014 Tentang

\footnotetext{
${ }^{1}$ Lihat pasal 1 ayat 1 UU No 6 Tahun 2014 Tentang Desa

${ }^{2}$ Lihat pasal 1 angka 2 Undang-Undang No 6 Tahun 2014 Tentang Desa

${ }^{3}$ Ibid.

${ }^{4}$ Ibid.
}

Desa Pasal 71 ayat 1 yakni semua hak dan kewajiban Desa yang dapat dinilai dengan uang serta segala sesuatu berupa uang dan barang yang berhubungan dengan pelaksanaan hak dan kewajiban Desa. ${ }^{5}$ Pasal 71 Ayat (2) Hak dan kewajiban menimbulkan pendapatan, belanja, pembiayaan, dan pengelolaan Keuangan Desa. ${ }^{6}$

Peraturan Pemerintah Nomor 47 tahun 2015 Tentang perubahan atas Peraturan Pemerintah Nomor 43 tahun 2014 tentang peraturan pelaksanaan UndangUndang nomor 6 tahun 2014 tentang desa pasal 1 ayat 8 dan 9 menjelaskan: Pasal 1 ayat 8 Dana Desa adalah dana yang bersumber dari anggaran pendapatan dan belanja negara yang diperuntukkan bagi Desa yang ditransfer melalui anggaran pendapatan dan belanja daerah kabupaten/kota dan digunakan untuk membiayai penyelenggaraan pemerintahan, pelaksanaan pembangunan, pembinaan kemasyarakatan, dan pemberdayaan masyarakat. ${ }^{7}$ dan pasal 1 ayat 9 Alokasi Dana Desa, selanjutnya disingkat ADD, adalah dana perimbangan yang diterima kabupaten/kota dalam anggaran pendapatan dan belanja daerah kabupaten/kota setelah dikurangi Dana Alokasi Khusus. ${ }^{8}$

Realitas yang terjadi terkait diamantkand dalam Undang-Undang Nomor. 6 tahun 2014 tentang Desa, terutama yang berkaitan dengan pengelolaan dana desa dalam konteks pemberdayaan masyarakat desa, dikaitkan dengan kondisi rill pemerintah Desa yang ada Kabupaten Dompu, menurut pengamatan awal peneliti,

\footnotetext{
${ }^{5}$ Lihat Pasal 1 angka (10) Undang Nomor 6 Tahun 2014 Tentang Desa

${ }^{6}$ Loc, Cit

${ }^{7}$ Lihat pasal 1 ayat 8 Peraturan Pemerintah Republik Indonesia Nomor 47 tahun 2015 Tentang perubahan atas Peraturan Pemerintah Nomor 43 tahun 2014 tentang peraturan pelaksanaan Undang-Undang nomor 6 tahun 2014 tentang desa

${ }^{8}$ Lihat Pasal 1 ayat 9 Peraturan Pemerintah Republik Indonesia Nomor 47 tahun 2015 Tentang perubahan atas Peraturan Pemerintah Nomor 43 tahun 2014 tentang peraturan pelaksanaan Undang-Undang nomor 6 tahun 2014 tentang desa
} 
Sahrul Haidin| Pelaksanaan Pengelolaan Keuangan Desa Setelah Berlakunya Undang-Undang Nomor.....

menunjukkan bahwa kepala Desa dan staf Desa dalam pelaksanaan kewenangannya terutama dalam pengelolaan dana Desa yang dibutuhkan untuk kepentingan perencanaan pembangunan, hasilnya belum terlaksana secara optimal. Hal ini terbukti dari pelaksanaan kewenangan pemerintah desa dalam pengelolaan dana Desa yang ada di sebagian wilayah Kabupaten Dompu yang tidak terlaksana dengan baik dan konsisten sesuai ketentuan, teruatama pertanggung jawaban pengelolaan dana Desa untuk pembangunan saranan dan prasarana Desa yang masih jauh dari harapan.

Tentu hal itu terjadi karena adanya pengaruh berbagai faktor, antara lain terutama faktor kemampuan sumber daya aparat Desa masih rendah, regulasi dan pengawasan yang belum maksimal. Hal ini dapat dijumpai kasus pengelolaan dana desa yang melibatkan sejumlah Desa yang ada di Kabupaten Dompu diantaranya Desa Saneo, Desa Ranggo, Desa Tekasire, Desa Soriutu dan Desa anamina tentu hal tersebut hasil evaluasi yang dilakukan BPMDES yang berkaitan erat laporan pertanggungjawaban penyelenggaran pemerintah terutama dalam penggunaan anggaran Desa ditemukan penyimpangan yang melibatkan kepala Desa dan stafnya.

Berdasarkan uraian di atas ada tiga hal yang menjadi permasalahan yang akan dikaji dalam tulisan ini yakni: Bagaimanakah pengaturan pelaksanaan pengelolaan keuagan Desa setelah berlakunya undang-undang No 6 tahun 2014 tentang Desa, apakah faktor yang menjadi hambatan dalam pelaksanaan pengelolaan keuangan Desa setelah berlakunya undang-undang No. 6 tahun 2014 tentang Desa dan bagaimanakah upaya penguatan dalam pelaksanaan pengelolaan keuangan Desa setelah berlakunya undangundang No. 6 tahun 2014 tentang Desa. Jenis pendekatan dalam penelitian ini adalah pendekatan perundang-undangan, pendekatan konseptual dan pendekatan sosiologis dan manfaat praktis dan akademis.

\section{PEMBAHASAN}

Untuk menjawab permasalahan dalam penelitian ini maka peneliti menggunakan beberapa teori sebagai instrumen untuk menganalisis masalah dalam penelitian yakni:

\section{a. Teori Pemerintahan}

Pemerintah (government) secara etimologis, berasal dari bahasa yunani kuno yaitu kubernan atau sebagai nahkoda kapal. Artinya menatap kedepan lalu perkataan memerintah berrati meilhat kedepan, menentukan berbagai kebijakan diselenggarakan untuk mencapai tujuan masyarakat atau negara, memperkirakan arah perkembangan masyarakat masa mendatang dan mempersiapkan langkah -langkah kebijakan untuk menyongsong perkembangan masyarakat serta mengelola dan mengarahkan masyarakat kepada tujuan yang telah ditetapkan. ${ }^{9}$

Tujuan pemerintahan Negara Indonesia pada umumnya terdapat dalam pembukaan UUD 1945 setelah amandemen. adalah melindungi segenap bangsa Indonesia dan untuk memajukan kesejahteraan umum, mencerdaskan kehidupan bangsa, serta ikut melaksanakan ketertiban dunia yang berdasarkan kemerdekaan, perdamaian abadi dan keadilan sosial. ${ }^{10}$

\section{b. Teori Desa}

Desa sendiri berasal dari bahasa india yakni "Swadesi" yang berarti tempat asal, tempat tinggal, negeri asal, atau tanah leluhur yang merujuk pada satu kesatuan hidup, dengan satu kesatuan norma, serta memiliki batas yang jelas (Soetardjo,

\footnotetext{
${ }^{9}$ Anthonius Sitepu, Teori Politik, Graha Ilmu, Yogyakarta, 2012, hal 47.

${ }^{10}$ Lihat pembukaan UUD 1945 setelah amandemen.
} 
Yulianti). ${ }^{11}$ Dengan kata lain secara etimologi kata desa berasal dari bahasa Sansekerta, deca yang berarti tanah air, tanah asal, atau tanah kelahiran. Desa adalah suatu kesatuan masyarakat hukum yang mempunyai susunan asli berdasarkan hak asal usul yang bersifat istimewa. ${ }^{12}$

Undang-undang No. 6 Tahun 2014 tentang Desa pasal 1 ayat 1 mendefinisikan Desa adalah desa dan desa adat atau yang disebut dengan nama lain, selanjutnya disebut Desa, adalah kesatuan masyarakat hukum yang memiliki batas wilayah yang berwenang untuk mengatur dan mengurus urusan pemerintahan, kepentingan masyarakat setempat berdasarkan prakarsa masyarakat, hak asal-usul, dan atau hak tradisional yang diakui dan dihormati dalam sistem pemerintahan Negara Kesatuan Republik Indonesia. ${ }^{13}$

\section{c. Teori Kewenangan}

Istilah kewenangan berasal dari terjamahan bahasa inggris yaitu authority of theory istilah yang digunakan dalam bahasa belanda yaitu theorie van het gezag. Sedangkan dalam bahasa jerman ialah theorie der autoritiit. Teori kewenangan berasal dari dua suku kata, yaitu teori dan kewenangan. ${ }^{14}$ Kewenangan yang dimiliki oleh organ (institusi) pemerintah dalam melakukan perbuatan nyata (ril) mengadakan pengaturan atau mengeluarkan keputusan selalu dilandasi oleh kewenangan yang diperoleh dari konstitusi secara atribusi, delegasi, maupun mandat. Suatu atribusi menunjuk pada kewenangan yang asli atas dasar konstitusi (undang-undang dasar). Pada kewenangan delegasi, harus

\footnotetext{
${ }^{11}$ Bintarto R, dalam Soetardjo, Yulianti Interaksi Desa-Kota dan Permasalahannya, Ghalia Indonesia, Jakarta, 2001 hal 64.

${ }^{12}$ Widjaja, Otonomi Desa Merupakan Otonomi Yang Asli, Bulat dan Utuh, Raja Grafindo Persada, jakarta, 2012 , hal 3.

${ }^{13}$ Lihat UU No 6 Tahun 2014 tentang Desa dalam ketentuan pasal 1 ayat 1 .

${ }^{14}$ Salim HS, dan Erlies Septiana Nurbani,. 2014. Penerapan Teori Hukum pada Peneltian Tesis dan Disertasi Penerbit Raja Grafindo Persada Jakarta hal 183-184.
}

ditegaskan suatu pelimpahan wewenang kepada organ pemerintah yang lain. Pada mandat tidak terjadi pelimpahan apapun dalam arti pemberian wewenang, akan tetapi, yang diberi mandat bertindak atas nama pemberian wewenang. Akan tetapi yang diberi mandat bertindak atas nama pemberi mandat. Dalam pemberian mandat, pejabat yang diberi mandat menunjuk pejabat lain untuk bertindak atas nama mandator (pemberi mandat). ${ }^{15}$

Menurut Philipus M. Hadjon istilah kewenangan ada sedikit perbedaan dengan istilah bevogheid. Perbedaan terletak pada karakter hukumnya. Istilah bevogheid dalam konsep hukum publik maupun dalam konsep hukum privat. Dalam sistem hukum indonesia kewenangan atau wewenang seharusnya hanya digunakan dalam konsep hukum publik. ${ }^{16}$

\section{d. Teori Manajemen Keuangan}

"Menajemen keuangan adalah suatu proses dalam pengaturan aktivitas atau kegiatan keuangan dalam suatu organisasi, di mana didalamnya termasuk kegiatan planning, analisis, dan pengendalian terhadap kegiatan keuangan yang biasanya dilakukan oleh manajemen keuangan ${ }^{17}$. Arti lain, manajemen keuangan merupakan hal yang berkaitan dengan kebijakan yang akan diambil dalam usaha pengendalian keuangan perusahaan agar biaya yang dikeluarkan atas investasi dapat efektik"18.

Secara Umum, Pengertian Manajemen Keuangan adalah suatu kegiatan yang terdiri dari perencanaan, penganggaran, pemeriksaan, pengelolaan, pengendalian,

\footnotetext{
${ }^{15}$ Nanang nugraha, Model Kewenangan Wakil Kepala Daerah Dalam Pemerintahan Daerah, Refika Aditama Bandung, 2013, hal 25.

${ }^{16}$ Himawan Estu Bagijo, Negara Hukum Dan Mahkamah Konstitusi Perwujudan Negara Hukum Yang Demokratis Melalui Wewenang Mahkamah Konstitusi Dalam Pengujian Undang-Undang, Laksbang Grafika, Yogyakarta, tahun 2014, hal 142.

${ }^{17}$ Asniani, Manajemen Keuangan, Teras, Yogyakarta, 2012, hal 1.

${ }^{18}$ Setia Mulyawan, Manajemen Keuangan, Pustaka Seta, Bandung, 2015, hal 30.
} 
Sahrul Haidin| Pelaksanaan Pengelolaan Keuangan Desa Setelah Berlakunya Undang-Undang Nomor.....

pencaharian dan penyimpanan dana yang dimiliki oleh suatu organisasi atau perusahaan. Sedangkan secara sederhana, Pengertian Manajemen Keuangan adalah suatu proses dalam aktivitas keuangan perusahaan, dimulai dari cara memperoleh dana dan mempergunakannya. Yang mana penggunaannya harus tepat sasaran, efisien, dan efektif agar tujuan keuangan perusahaan dapat tercapai sesuai rencana. ${ }^{\mathbf{1 9}}$

\section{e. Teori Pertanggung jawaban}

Tanggung jawab hukum, yang dalam bahasa inggris disebut dengan the theory of legal liability, bahasa belanda disebut de theorie van wettelijke aansprakelijkheid, sedangkan dalam bahasa jerman die theorie der haftung merupakan teori yang menganalisis tentang tanggung jawab subyek hukum atau pelaku yang telah melakukan perbuatan melawan hukum atau perbuatan pidana sehingga menimbulkan kerugian atau cacat, atau matinya orang lain. ${ }^{20}$ Menurut Roscoe Pound, hukum melihat ada tiga pertanggung jawaban atas delik yaitu:

a. Pertanggung jawaban atas perugian yang di sengaja;

b. Pertanggungjawabanatasperugiankarena kealpaan dan tidak disengaja;

c. Pertanggung jawaban dalam perkara tertentu atas perugian yang dilakukan karena kelalaian serta tidak disengaja. ${ }^{21}$

\section{f. Konsep Otonomi Desa}

Otonomi desa adalah hak untuk mengatur dan mengurus rumah tangganya sendiri yang terbentuk bersamaan dengan terbentuknya persekutuan masyarakat hokum

${ }^{19}$ Ridwan H.R, Hukum Administrasi Negara, Raja Grafindo Persada, Jakarta, 2006, hlm. 335-337.

${ }^{20}$ Salim Hs dan Erlies Setiana Nurbani, Penerapan Teori Hukum Pada Penelitian Desertasi dan Tesis, Raja Grafindo Persada Jakarta. Tahun 2015, hal 207.

${ }^{21}$ Roscoe Pound Dalam I Gusti Bagus Yoga Prawira Tanggung jawab Ppat Terhadap Akta Jual Beli Tanah Jurnal IUS 2016 Kajian Hukum Dan Keadilan Vol IV | Nomor 1 hal 17. tersebut, dengan batas-batas berupa hak dan kewenangan yang belum diatur oleh persekutuan masyarakat hokum yang lebih luas dan tinggi tingkatannya, dalam rangka memenuhi kebutuhan hidup dan penghidupan kesatuan masyarakat hukum bersangkutan. ${ }^{22}$ Desa yang otonom akan memberikan ruang gerak yang luas pada perencanaan pembangunan yang merupakan kebutuhan nyata masyarakat dan tidak banyak dibebani oleh program-program kerja dari berbagai instansi dan pemerintah. ${ }^{23}$

Menurut Undang-Undang No. 6 Tahun 2014 tentang Desa Pasal 18 kewenangan desa meliputi kewenangan di bidang penyelenggaraan pemerintahan desa, pelaksanaan pembangunan desa, pembinaan kemasyarakatan desa, dan pemberdayaan masyarakat desa berdasarkan prakarsa masyarakat, hak asal-usul, dan adat-istiadat desa. ${ }^{24}$

Bentuk kemandirian desa terdapat dalam Undang-Undang Nomor 32 Tahun 2004 tentang Pemerintahan Daerah Pasal 200 dan 216 menyatakan bahwa desa di kabupaten/kota memiliki kewenangan-kewenangan yang dapat diatur secara bersama antara pemerintah desa dan BPD yang dimaksudkan untuk meningkatkan pelayananan kepada masyarakat. Penyelenggaraan desa yang otonom dengan kewenangan yang di limpahkan tersebut pada dasarnya merupakan proses yang terjadi secara simultan dan berkesinambungan yang memerlukan pengetahuan aparatur daerah tentang kewenangan mereka, potensi daerah dan menjaring aspirasi masyarakat di wilayahnya.

Dalam Undang-Undang No. 32 Tahun 2004 disebutkan urusan pemerintahan

\footnotetext{
${ }^{22}$ Sadu Wasistiono dalam Edy Supriadi. Pertanggungjawaban Kepala Desa Dalam Pengelolaan Keuangan Desa Berdasarkan Undang-Undang Nomor 6 Tahun 2014 Tentang Desa. Jurnal IUS 2015 (Kajian Hukum dan Keadilan), Vol III | Nomor 8 hal 4.

${ }^{23}$ Ibid

${ }^{24}$ Lihat Pasal 18 Undang-Undang No. 6 Tahun 2014 tentang Desa
} 
yang menjadi kewenangan desa mencakup: urusan pemerintahan yang sudah ada berdasarkan hak asal usul desa, urusan pemerintahan yang menjadi kewenangan Kabupaten/kota yang diserahkan pengaturannya kepada desa, tugas pembantuan dari Pemerintah, Pemerintah provinsi, dan atau pemerintah Kabupaten/kota dan yang terakhir urusan pemerintahan lainnya yang oleh peraturan perundang-perundangan diserahkan kepada desa. Tugas pembantuan dari Pemerintah, Pemerintah Provinsi, dan/ atau pemerintah Kabupaten/kota kepada desa disertai dengan pembiayaan, sarana dan prasarana, serta sumber daya manusia.

\section{g. Konsep Keuangan Desa}

Keuangan desa dijelaskan dalam Undang Undang No 6 Tahun 2014 Tentang Desa Pasal 71 ayat 1 yakni semua hak dan kewajiban Desa yang dapat dinilai dengan uang serta segala sesuatu berupa uang dan barang yang berhubungan dengan pelaksanaan hak dan kewajiban Desa. Selanjutnya Pasal 71 Ayat (2) menyebutkan bahwa Hak dan kewajiban menimbulkan pendapatan, belanja, pembiayaan, dan pengelolaan Keuangan Desa. ${ }^{25}$

Peraturan Pemerintah No 47 tahun 2015 Tentang perubahan atas Peraturan Pemerintah No 43 tahun 2014 tentang peraturan pelaksanaan Undang-Undang No 6 tahun 2014 tentang desa pasal 1 ayat 8 dan 9 menjelaskan: Pasal 1 ayat 8 Dana Desa adalah dana yang bersumber dari anggaran pendapatan dan belanja negara yang diperuntukkan bagi Desa yang ditransfer melalui anggaran pendapatan dan belanja daerah kabupaten/kota dan digunakan untuk membiayai penyelenggaraan pemerintahan, pelaksanaan pembangunan, pembinaan kemasyarakatan, dan pemberdayaan masyarakat. ${ }^{26}$ Pasal

${ }^{25}$ Lihat pasal 71 ayat 1 dan 2Undang Undang No 6 Tahun 2014 Tentang Desa

${ }^{26}$ Lihat pasal 1 ayat 8 Peraturan Pemerintah Republik Indonesia Nomor 47 tahun 2015 Tentang perubahan atas Peraturan Pemerintah Nomor 43 tahun 2014 ten-
1 ayat 9 Alokasi Dana Desa, selanjutnya disingkat $\mathrm{ADD}$, adalah dana perimbangan yang diterima kabupaten/kota dalam anggaran pendapatan dan belanja daerah kabupaten/kota setelah dikurangi Dana Alokasi Khusus. $^{27}$

Permendagri No 113 tahun 2014 tentang pengelolaan keuangan desa Pasal 1 ayat 5. Keuangan Desa adalah semua hak dan kewajiban Desa yang dapat dinilai dengan uang serta segala sesuatu berupa uang dan barang yang berhubungan dengan pelaksanaan hak dan kewajiban Desa. ${ }^{28}$

Prinsip pengeloaan keuangan di Desa dalam rangka Good Governance harus mencakup beberapa aspek diantaranya adalah:

1. Aspiratif, dalam pengambilan kebijakan tentang pengelolaan keuangan Desa pemerintah desa dan BPD harus mendengar aspirasi dari masyarakat.

2. Partisipatif,dalampengambilankebijakan pengelolaan keuangan Desa, pemerintah desa harus melibatkan masyarakat.

3. Transparan, masyarakat memperoleh informasi yang cukup tentang APBDes, termasuk program pembangunan,lelang kas Desa, bantuan pemerintah dan pungutan ke masyarakat.

4. Akuntabilitas, dalam mengelola keungan desaharusberdasarkankepalaaturanyang berlaku. $^{29}$

\section{Pengaturan Pelaksanaan Pengelolaan Keuangan Desa Setelah Berlakunya Undang-Undang No 6 Tahun 2014 Tentang Desa}

\section{a. Dasar Pengaturan Pengelolaan Keuangan Desa}

tang peraturan pelaksanaan Undang-Undang nomor 6 tahun 2014 tentang desa

${ }^{27}$ ibid

${ }^{28}$ Lihat Pasal 1 ayat 5 Peraturan menteri dalam negeri Republik Indonesia Nomor 113 tahun 2014 tentang pengelolaan keuangan desa

${ }_{29}$ Edy Supriadi. Pertanggungjawaban Kepala Desa Dalam Pengelolaan Keuangan Desa Berdasarkan Undang-Undang Nomor 6 Tahun 2014 Tentang Desa. Jurnal IUS (Kajian Hukum dan Keadilan),Vol III | Nomor 8 
Sahrul Haidin| Pelaksanaan Pengelolaan Keuangan Desa Setelah Berlakunya Undang-Undang Nomor.....

Kebijakan yang berupa undang-undang maupun aturan lain tentu memiliki dasar untuk dijadikan sebagai acuan dalam pembuatannya termasuk Pengakuan Pemerintah Republik Indonesia terhadap desa. Pemerintah Desa tidak disebutkan secara jelas dalam UUD 1945. Namun ditafsirkan dalam Pasal 18B Undang-Undang Dasar Negara Republik Indonesia Tahun 1945 sebagai berikut :

1. Negara mengakui dan menghormati satuan-satuan pemerintahan daerah yang bersifatkhususataubersifatistimewayang diatur dengan undang-undang.

2. Negara mengakui dan menghormati kesatuan-kesatuan masyarakat hukum adat beserta hak-hak tradisionalnya sepanjang masih hidup dan sesuai dengan perkembangan masyarakat dan prinsip NegaraKesatuanRepublikIndonesia,yang diatur dalam undang-undang. ${ }^{30}$

Bertitik tolak pada pengertian sebagaimana ketentuan diatas, terlihat bahwa Desa (atau dengan nama lain) sebagai sebuah pemerintahan yang otonom dan diakui keberadaannya oleh Negara yakni Pemerintah Indonesia. Sebagaimana suatu pemerintahan, Desa mempunyai tugas dan fungsi untuk menyelenggarakan Pemerintahan Desa, melaksanakan Pembangunan Desa, pembinaan kemasyarakatan Desa, dan pemberdayaan masyarakat Desa. Keuangan desa, dalam UndangUndang No 6 Tahun 2014 Tentang Desa Pasal 1 angka (10) semua hak dan kewajiban Desa yang dapat dinilai dengan uang serta segala sesuatu berupa uang dan barang yang berhubungan dengan pelaksanaan hak dan kewajiban Desa. Pasal 71 Ayat (2) menyebutkan bahwa Hak dan kewajiban menimbulkan pendapatan, belanja, pembiayaan, dan pengelolaan Keuangan Desa. ${ }^{31}$

\footnotetext{
${ }^{30}$ Lihat Pasal 18B Undang-Undang Dasar Negara Republik Indonesia 1945 Hasil Amandemen

${ }^{31}$ Lihat Pasal 1 angka (10) Undang Undang Nomor 6 Tahun 2014 Tentang Desa.
}

Peraturan Pemerintah No 47 tahun 2015 Tentang perubahan atas Peraturan Pemerintah No 43 tahun 2014 tentang peraturan pelaksanaan Undang-Undang No 6 tahun 2014 tentang desa pasal 1 ayat 8 dan 9 menjelaskan: Pasal 1 ayat 8 Dana Desa adalah dana yang bersumber dari anggaran pendapatan dan belanja negara yang diperuntukkanbagi Desayang ditransfer melalui anggaran pendapatan dan belanja daerah kabupaten/kota dan digunakan untuk membiayai penyelenggaraan pemerintahan, pelaksanaan pembangunan, pembinaan kemasyarakatan, dan pemberdayaan masyarakat dan pasal 1 ayat 9 Alokasi Dana Desa, selanjutnya disingkat ADD, adalah dana perimbangan yang diterima kabupaten/ kota dalam anggaran pendapatan dan belanja daerah kabupaten/kota setelah dikurangi Dana Alokasi Khusus. Permendagri No 113 tahun 2014 tentang pengelolaan keuangan desa pasal 1 ayat 5, 6, 9 dan 10 menjelaskan: Pasal 1 ayat 5. Keuangan Desa adalah semua hak dan kewajiban Desa yang dapat dinilai dengan uang serta segala sesuatu berupa uang dan barang yang berhubungan dengan pelaksanaan hak dan kewajiban Desa. Dan pasal 1 ayat 6 Pengelolaan Keuangan Desa adalah keseluruhan kegiatan yang meliputi perencanaan, pelaksanaan, penatausahaan, pelaporan, dan pertanggungjawaban keuangan desa, pasal 1 ayat 9 Dana Desa adalah dana yang bersumber dari Anggaran Pendapatan dan Belanja Negara yang diperuntukkan bagi Desa yang ditransfer melalui Anggaran Pendapatan dan Belanja Daerah Kabupaten/Kota dan digunakan untuk membiayai penyelenggaraan pemerintahan, pelaksanaan pembangunan, pembinaan kemasyarakatan, dan pemberdayaan masyarakat dan pasal 1 ayat 10 yakni Alokasi Dana Desa, selanjutnya disingkat ADD, adalah dana perimbangan yang diterima kabupaten/kota dalam Anggaran Pendapatan dan Belanja Daerah kabupaten/kota setelah dikurangi Dana Alokasi Khusus. 
Peraturan Menteri Desa, Pembangunan Daerah Tertinggal, dan Transmigrasi Nomor 5 tahun 2015 tentang penetapan prioritas penggunaan dana desa tahun 2015 Pasal 2, pasal 3 dan pasal 4 Pasal yakni: Pasal 2 Dana Desa yang bersumber dari APBN digunakan untuk mendanai pelaksanaan kewenangan berdasarkan hak asal usul dan kewenangan lokal berskala Desa yang diatur dan diurus oleh Desa, Pasal 3 Dana Desa diprioritaskan untuk membiayai belanja pembangunan pemberdayaan masyarakat Desa dan Pasal 4 Penggunaan Dana Desa tertuang dalam prioritas belanja Desa yang disepakati dalam Musyawarah Desa. Pasal 2 Dana Desa yang bersumber dari APBN digunakan untuk mendanai pelaksanaan kewenangan berdasarkan hak asal usul dan kewenangan lokal berskala Desa yang diatur dan diurus oleh Desa. Pasal 3 Dana Desa diprioritaskan untuk membiayai belanja pembangunan dan pemberdayaan masyarakat Desa. Pasal 4 Penggunaan Dana Desa tertuang dalam prioritas belanja Desa yang disepakati dalam Musyawarah Desa.

Pasal 5 Prioritas penggunaan Dana Desa untuk pembangunan Desa dialokasikan untuk mencapai tujuan pembangunan Desa yaitu meningkatkan kesejahteraan masyarakat Desa dan kualitas hidup manusia serta penanggulangan kemiskinan, melalui:

a. pemenuhan kebutuhan dasar;

b. pembangunan sarana dan prasarana Desa;

c. pengembangan potensi ekonomi lokal; dan

d. pemanfaatan sumber daya alam dan lingkungan secara berkelanjutan.

Pasal 6 Prioritas penggunaan Dana Desa sebagaimana dimaksud dalam Pasal 5 huruf a, meliputi:

a. pengembangan poskesehatanDesadan Polindes; b. pengelolaan dan pembinaan Posyandu; dan

c. pembinaan dan pengelolaan pendidikan anak usia dini.

Pasal 7 Prioritas penggunaan Dana Desa sebagaimana dimaksud dalam Pasal 5 huruf b dan huruf c untuk mendukung target pembangunan sektor unggulan dalam Rencana Pembangunan Jangka Menengah Nasional (RPJMN) 2015-2019 dan Rencana Kerja Pemerintah (RKP) setiap tahunnya, yang diprioritaskan untuk:

a. mendukung kedaulatan pangan;

b. mendukung kedaulatan energi;

c. mendukung pembangunan kemaritiman dan kelautan; dan

d. mendukung pariwisata dan industri.

Pasal 8 Prioritas penggunaan Dana Desa sebagaimana dimaksud dalam Pasal 5 huruf b didasarkan atas kondisi dan potensi Desa, sejalan dengan pencapaian target RPJM Desa dan RKP Desa setiap tahunnya, yang diantaranya dapat meliputi:

a. pembangunan dan pemeliharaan jalan Desa;

b. pembangunan dan pemeliharaan jalan usaha tani;

c. pembangunan dan pemeliharaan embung Desa;

d. pembangunan energi baru dan terbarukan;

e. pembangunan dan pemeliharaan sanitasi lingkungan;

f.pembangunandanpengelolaanairbersih berskala Desa;

g. pembangunan dan pemeliharaan irigasi tersier;

h. pembangunan dan pemeliharaan serta pengelolaan saluran untuk budidaya perikanan; dan 
Sahrul Haidin| Pelaksanaan Pengelolaan Keuangan Desa Setelah Berlakunya Undang-Undang Nomor.....

i. pengembangan sarana dan prasarana produksi di Desa.

Pasal 9 Prioritas penggunaan Dana Desa sebagaimana dimaksud dalam Pasal 5 huruf c didasarkan atas kondisi dan potensi Desa, sejalan dengan pencapaian target RPJM Desa dan RKP Desa setiap tahunnya, yang diantaranya dapat meliputi:

a. pendirian dan pengembangan BUM Desa;

b. pembangunan dan pengelolaan pasar Desa dan kios Desa;

c. pembangunan dan pengelolaan tempat pelelangan ikan milik Desa;

d.pembangunandanpengelolaankeramba jaring apung dan bagan ikan;

e.pembangunandanpengelolaanlumbung pangan Desa;

f. pembuatan pupuk dan pakan organik untuk pertanian dan perikanan;

g. pengembangan benih lokal;

h. pengembangan ternak secara kolektif;

i. pembangunan dan pengelolaan energi mandiri;

j.pembangunandanpengelolaantambatan perahu;

k. pengelolaan padang gembala;

1. pengembangan Desa Wisata; dan

m.pengembangan teknologi tepat guna pengolahan hasil pertanian dan perikanan.

Pasal 10 Prioritas penggunaan Dana Desa sebagaimana dimaksud dalam Pasal 5 huruf d, didasarkan atas kondisi dan potensi Desa, sejalan dengan pencapaian target RPJM Desa dan RKP Desa setiap tahunnya.

Pasal 11 Penggunaan Dana Desa yang bersumber dari APBN untuk
Pemberdayaan Masyarakat Desa terutama untuk penanggulangan kemiskinan dan peningkatan akses atas sumber daya ekonomi, sejalan dengan pencapaian target RPJM Desa dan RKP Desa setiap tahunnya, yang diantaranya dapat mencakup:

a. peningkatan kualitas proses perencanaan Desa;

b. mendukung kegiatan ekonomi baik yang dikembangkan oleh BUM Desa maupun oleh kelompok usaha masyarakat Desa lainnya;

c. pembentukan dan peningkatan kapasitas Kader Pemberdayaan Masyarakat Desa;

d. pengorganisasian melalui pembentukan dan fasilitasi paralegal untuk memberikan bantuan hukum kepada warga masyarakat Desa;

e. penyelenggaraan promosi kesehatan dan gerakan hidup bersih dan sehat;

f. dukungan terhadap kegiatan desa dan masyarakat pengelolaan Hutan Desa dan Hutan Kemasyarakatan; dan

g. peningkatan kapasitas kelompok masyarakat melalui: kelompok usaha ekonomi produktif, kelompok perempuan, kelompok tani, kelompok masyarakatmiskin, kelompok nelayan, kelompok pengrajin, kelompok pemerhati dan perlindungan anak, kelompok pemuda dan kelompok lain sesuai kondisi Desa.

\section{b. Sistem Akutansi Pengeturan Pengelolaan Keuangan Desa}

Peraturan Pemerintah yang menjadi pedoman untuk mengatur Keuangan Desa seperti yang diamanatkan pada beberapa pasal dalam undang-undang tersebut. Memang penyusunan sistem akuntansi di tingkat desa ini menjadi cukup rumit karena permasalahan sumber daya manusia dan banyaknya desa yang akan 
melaksanakannya, yaitu sebanyak +/- 78 ribu desa di Indonesia termasuk 72 Desa dari 8 Kecamatan yang ada di Kabupaten Dompu.

Membahas tentang Sistem Informasi Akuntansi. Untuk sistem informasi secara umum sudah diatur oleh Undang-Undang No.6 tahun2014 tentang Desa pada pasal 86 menjelaskan:

1. Desaberhakmendapatkanaksesinformasi melalui sistem informasi Desa yang dikembangkan oleh Pemerintah Daerah Kabupaten/Kota.

2. Pemerintah dan Pemerintah Daerah wajib mengembangkan sistem informasi Desa dan pembangunan Kawasan Perdesaan.

3. Sistem informasi Desa sebagaimana dimaksud pada ayat (2) meliputi fasilitas perangkat keras dan perangkat lunak, jaringan, serta sumber daya manusia.

4. Sistem informasi Desa sebagaimana dimaksud pada ayat (2) meliputi data Desa, data Pembangunan Desa, Kawasan Perdesaan, serta informasi lain yang berkaitan dengan Pembangunan Desa dan pembangunan Kawasan Perdesaan.

5. Sistem informasi Desa sebagaimana dimaksud pada ayat (2) dikelola oleh Pemerintah Desa dan dapat diakses oleh masyarakat Desa dan semua pemangku kepentingan.

6. Pemerintah Daerah Kabupaten/Kota menyediakan informasi perencanaan pembangunan Kabupaten/Kota untuk Desa.

Tanggung-jawab pengembangan sistem informasi desa ini diserahkan kepada Pemerintah Kabupaten/kota. Informasi yang dikelola dalam sistem tersebut adalah informasi umum yang cenderung lebih luas dan berbeda-beda ragamnya antar kabupaten, sesuai dengan perbedaan fokus pembangunan di daerah masing-masing.
Sedangkan pembahasan sistem informasi akuntansi adalah spesifik dan mempunyai standar yang sama pada seluruh desa di Indonesia seperti masa sebelumnya, diatur oleh Permendagri No.37/2007 tentang Pedoman Pengelolaan Keuangan Desa. Karena itu pengembangan sistem informasi akuntansi yang dilakukan pada beberapa bagian, ada yang di pusat, ada yang di pemerintah daerah, dan ada yang di desa itu sendiri yang semuanya memanfaatkan jaringan komunikasi data selular dengan tujuan keseragaman sistem dan memperkecil biaya investasi perangkat keras.

Dalam bidang akuntansi, Pemerintah sendiri khususnya di Pemda Kabupaten Dompu masih belum tuntas dalam merevisi proses akuntansinya agar dapat menghasilkan laporan keuangan berbasis akrual seperti yang diharapkan oleh PP No. 71/2010 tentang "Standar Akuntansi Pemerintah" (SAP). PP tersebut mengatur tentang perubahan standar akuntansi dari yang sebelumnya akuntansi berbasis kas menjadi berbasis akrual. Saat ini masih diberlakukan peraturan transisi yang disebut Standar Akuntansi Pemerintahan berbasis Kas menuju Akrual.

Pemerintahnya sendiri memerlukan waktu selama 4 tahun (sejak 2010) dan belum menuntaskan transisi laporan keuangan berbasis kas menjadi berbasis akrual, bagaimana nantinya kira-kira proses akuntansi yang harus dilakukan oleh ke 78 ribu desa termasuk 72 Desa yang ada di 8 Kecamatan Kabupaten Dompu yang umumnya memiliki sumberdaya manusia yang terbatas.

Saat ini masih berlaku Peraturan Menteri Dalam Negeri No.37/2007 tentang Pedoman Pengelolaan Keuangan Desa yang menjadi peraturan pelaksana dari UU No.32/2004 tentang Pemerintahan Daerah. Dalam Permendagri tersebut disebutkan bahwa pengelolaan keuangan desa 
Sahrul Haidin| Pelaksanaan Pengelolaan Keuangan Desa Setelah Berlakunya Undang-Undang Nomor.....

dilaksanakan oleh perangkat desa antara lain, Bendahara Desa dan Pelaksana Teknis Pengelolaan Keuangan Desa (PTPKD). Sedangkan dokumen yang disebutkan dalam Permendagri yang harus digunakan dalam pengelolaan keuangan desa tersebut adalah:

\section{Pesan publik khas}

2. Buku kas pembantu perincian obyek penerimaan

3. Buku kas pembantu Perincian obyek produksi

4. Buku kas harian pembantu.

Dengan pemahaman atas situasi dan kondisi dari pengelolaan keuangan desa saat ini, dihadapkan pada fakta bahwa pada tahun 20016 pencairan dana desa di Indonesia termasuk 72 Desa di Kabupaten Dompu sudah dilaksanakan. Kesiapan aparat, prosedur dan alat bantu pengelolaan keuangan di tingkat desa harus dapat dilakukan dengan baik. Di satu sisi Desa diberi tugas untuk menyelenggarakan urusan pemerintahan sehingga untuk pencatatan dan pertanggung-jawaban pengelolaan keuangannya seharusnya mengikuti standar akuntansi yang dikeluarkan pemerintah yang telah diatur dalam PP no.71/2010.

\section{Faktor Yang Menjadi Hambatan Pelaksanaan Pengelolaan Keuangan Desa Setelah Berlakunya Undang- Undang No. 6 Tahun 2014 tentang desa}

\section{a. Pelaksanaan pengelolaan keuangan Desa}

Eksistensi Desa Pelaksanaan pengelolaan keuangan Desa merupakan bagian dari otonomi Desa dalam hal diberi kewenangan untuk mengatur desanya secara mandiri baik pengelolaan keuangan Desa termasuk bidang sosial, politik dan ekonomi. Dengan adanya kemandirian ini diharapkan akan dapat meningkatkan sarana infrastruktur pembangunan untuk memenuhi kebutuhan masyarakat setempat selain itu partisipasi masyarakat desa dalam pengelolaan keuangan Desa sangat diperlukan.

Pasal 18 Undang-undang Dasar 1945, terdapat tiga asas penyelenggaraan pemerintahan daerah yang implementasinya dalam pelaksanaan pemerintahan desa, yaitu:

1. Desentralisasi, artinya penyerahan wewenangpemerintahanolehpemerintah kepada daerah otonom untuk mengatur dan mengurus urusan pemerintahan dalam sistem Negara Kesatuan Republik Indonesia;

2. Desentralisasi, artinya pelimpahan wewenangpemerintahanolehpemerintah kepadagubernursebagaiwakilpemerintah dan/atau kepada instansi vertikal di wilayah tertentu;

3. Tugas pembantuan, artinya penugasan dari pemerintah kepada daerah dan/atau desa dari pemerintah propinsi kepada kabupaten/kota dan/atau desa serta dari pemerintah kabupaten/kota kepada desa untuk melaksanakan tugas tertentu.

Menurut Undang-Undang No. 6 Tahun 2014 tentang Desa Pasal 19 UndangUndang No. 6 Tahun 2014 tentang Desa kewenangan desa meliputi:

a. kewenangan berdasarkan hak asal-usul;

b. kewenangan lokal berskala Desa;

c. kewenangan yang ditugaskan oleh Pemerintah, Pemerintah Daerah Provinsi, atauPemerintahDaerahKabupaten/Kota; dan

d. kewenangan lain yang ditugaskan oleh Pemerintah, Pemerintah Daerah Provinsi, atau Pemerintah Daerah Kabupaten/ Kota sesuai dengan ketentuan peraturan perundang-undangan. 
Berkaitan dengan keberadaan undangundang no 6 tahun 2014 tentang Desa yang menyangkut kewenangan pengelolaan dana Desa di atur dalam Peraturan Pemerintah Nomor 60 Tahun 2014 tentang Dana Desa yang bersumber dari APBN, Pasal 1, ayat 2 pasal 5 ayat 1 dan pasal $6:^{32}$ Pasal 1 ayat 2 dana Desa adalah Dana yang bersumber dari Anggaran Pendapatan dan Belanja Negara yang diperuntukkan bagi Desa yang ditransfer melalui Anggaran Pendapatan dan Belanja Daerah Kabupaten/Kota dan digunakan untuk membiayai penyelenggaraan pemerintahan, pelaksanaan pembangunan, pembinaan kemasyarakatan, dan pemberdayaan masyarakat. Selanjutnya pasal 5 ayat 1 menyebutkan Dana Desa dialokasikan oleh Pemerintah Untuk Desa. Pengalokasian Dana Desa sebagaimana dimaksud pada ayat (1) dihitung berdasarkan jumlah Desa dan dialokasikan dengan memperhatikan jumlah penduduk, angka kemiskinan, luas wilayah dan tingkat kesulitan geografis. Psal 6 disebutkan Dana Desa tersebut ditransfer melalui APBD kabupaten/kota untuk selanjutnya ditransfer ke APBDesa.

Relitas yang terjadi dilapangaan khususnya Desa yang ada di Kabupaten Dompu bahwa implementasi Undangundang No 6 tahun 2014 tentang Desa, terutamatentangkewenanganpemerintahan Desa dalam pengelolaan dana desa dalam konteks pembangunan dan pemberdayaan masyarakat Desa, dikaitkan dengan kondisi rill pada pemerintah Desa di Kabupaten Dompu.berdasarkan hasil pengamatan awal peneliti, menunjukkan bahwa sejumlah kepala Desa dan staf Desa yang ada di Kabupaten Dompu terkait pelaksanaan kewenangannya terutama dalam pengelolaan dana Desa yang diperuntukan dalam meningkatkan pemberdayaan dan perencanaan pembangunan untuk kepentingan masyarakat setempat, hasilnya

32 Lihat Peraturan Pemerintah Nomor 60 Tahun 2014 tentang Dana Desa yang bersumber dari APBN, Pasal 1 , ayat 2 pasal 5 ayat 1 dan pasal 6 . masih minim atau belum terlaksana secara optimal.

Adapun hasil wawancara dengan beberapa narasumber baik dari BPMD, Camat, Kepala Desa dan BPD yang ada Kabupaten Dompu antara lain adalah antara lain:

Wwawancara dengan bapak H. Supardi, kepala BPMPD Dompu: Pelaksanaan kewenangan pemerintah desa yang ada di Kabupaten Dompu dalam pengelolaan dana Desa yang tidak terlaksana dengan baik dan konsisten sesuai ketentuan, teruatama menyangkut pertanggungjawaban pengelolaan dana Desa untuk pembangunan saranan dan prasarana Desa yang masih jauh dari yang diharapkan. Tentu hal itu terjadi karena adanya pengaruh berbagai faktor, antara lain terutama faktor pengetahuan kepala Desa sebagai penyelenggara yang belum optimal. Hal ini dapat dijumpai kasus pengelolaan dana desa yang melibatkan sejumlah kepala Desa misalnya kepala Desa tekasire, kepala Desa Ranggo, Kepala Desa Tanju, Kepala Desa Anamina, Kepala Desa Sorinomo, Kepala Desa Soriutu yang diduga terindikasi adanya penyimpangan yang mengarah KKN ${ }^{33}$ Bapak Muhamad Ridwan, Esensi kepala Desa sebagai pelaksana kewenangan pemerintah Desa terkadang menyalahi kwenangan yang diberikan oleh Undang-Undang Desa, tentu hal tersebut terbukti dari hasil evaluasi yang dilakukan oleh BPMDES Kabupaten Dompu yang berkaitan erat laporan pertanggungjawaban pengelolaan Dana Desa dalam penyelenggaran pemerintah Desa Tekasire terutama dalam penggunaan anggaran untuk pembangunan sarana dan prasarana infrastruktur Desa ditemukan adanya penyimpangan dalam penggunaan anggaran yang terindikasi korupsi, yang melibatkan kepala Desa dan stafnya. Masalah tersebut berawal dari laporan masyarakat setempat baik pada BPMD maupun lembaga hukum dalam hal

${ }^{33}$ Hasil wawancara dengan bapak $\mathrm{H}$. Supardi kepala BPMPD Kabupaten Dompu tanggal-4.Mei 2016. 
Sahrul Haidin| Pelaksanaan Pengelolaan Keuangan Desa Setelah Berlakunya Undang-Undang Nomor.....

ini kejaksaan Kabupaten Dompu untuk dilakukan upaya hukum. ${ }^{34}$

Bapak Suryadin, Penggunaan dana desa yang akan berikan pemerintah pusat langsung kepada perangkat desa termasuk Desa yang ada Kabupaten Dompu rawan terjadinya penyelewengan apabila pengelolaan dana desa tersebut tidak melibatkan fasilitator atau pendamping masyarakat desa. Kerawanan tersebut disebabkan minimnya pengawasan terhadap penggunaan dana desa dan rendahnya kemampuan perangkat desa dalam pengelolaan maupun penataan administrasi penggunaan dana desa tersebut. Tanpa fasilitator, penggunaan dana Desa Rawan Penyelewengan meskipun itu tidak ada jaminan mutlak. Tidak dapat dipungkiri bahwa perangkat desa biasanya hanya mampu mengerjakan proyek pembangunan dan kerapkali mengabaikan pencatatan dan pelaporan penggunaan anggaran. ${ }^{35}$ Bapak Irawan, Kepala Desa yang kerapkali menyalahgunakan kewenanganya tersebut membuat dana pembangunan desa sering tidak dapat dipertanggung-jawabkan. Tanpa bantuan fasilitator, masyarakat desa dan perangkat desa mengalami kesulitan mengelola dana pembangunan desa. Dana tersebut harus benar-benar digunakan membiayai pembangunan dan pemberdayaan masyarakat desa. Misalnya pembangunan berbagai sarana penunjang untuk kesejahteraan masyarakat namun sebalik hal seringkali muncul adalah adanya penyimpangan dalam pelaksanaanya pengelolaan dana desa yang melibatkan kepala Desa dan sataf.

\section{b. Hambatan Pelaksanaan Pengelolaan Keuangan Desa}

Sebelum peneliti menguraikan terkait hambatan dalam pengeiolaan keuangan Desa yang ada wilayah Kabupaten Dompu,

\footnotetext{
${ }^{34}$ Hasil wawancara dengan bapak Muhamad Ridwan, bidang pemerintahan Kecamatan Woja Kabupaten Dompu tanggal-9 Mei 2016.

${ }^{35}$ Hasil wawancara dengan bapak Suryadin, selaku kepala Desa Madaprama Kecamatan Woja Kabupaten Dompu tanggal-12 Mei 2016.
}

terlebih dahulu peneliti akan menjelaskan tentang Permendagri No. 113 Tahun 2014 tentang Pengelolaan Keuangan Desa, ihwal pengelolaan dan desa telah diatur dalam $\mathrm{Bab}$ V. Di dalamnya, diatur bahwa pengelolaan dana desa terdiri atas lima hal, yakni:

\section{Perencanaan;}

2. Pelaksanaan;

3. Penata usahaan;

4. pelaporan dan;

\section{Pertanggung jawaban.}

Apabila ditilik mulai dari hulu, pengelolaan keuangan desa dimulai dari perencanaan. Pertama kali diadakan musyawarah desa yang diselenggarakan oleh Badan Permusyawaratan Desa (BPD) untuk membahas hal-hal yang sifatnya strategis. ${ }^{36} \mathrm{Ke}$ mudian, hasil musyawarah desa berupa perencanaan pembangunan desa ditindak lanjuti dengan musyawarah pembangunan perencanaan desa (musrenbangdes) yang diselenggarakan kepala desa dan perangkatnya. Musrenbangdes inilah yang membahas mengenai Rencana Pembangunan Jangka Menengah Desa (RPJMDes) tiap enam tahun sekali dan Rencana Kerja Pemerintah Desa (RKPDes) serta APBDes tiap setahun sekali.

Berangkat dari persoalan tersebut tentu yang menjadi hambatan dalam pengelolaan keuangan Desa dari hasil keterangan beberapa narasumber baik dari BPMD, Camat, Kepala Desa dan BPD yang ada Kabupaten Dompu antara lain adalah antara lain:

1. Rendahnya pendidikan sumber daya manusia

Bapak Sugeng, SH selaku kepala subdidang BPMPD Kabupaten Dompu: Minimnya pendidikan berkaitan erat dengan pengetahuan dan keterampilan yang dimiliki oleh aparat pemerintah dalam hal ini kepala Desa yang kurang memiliki pengetahuan yang

\footnotetext{
${ }^{36}$ Lihat Pasal 54 Undang-Undang tentang Desa.
} 
memadai untuk mendukung pelaksanaan tugasnya pengelolaan manajemen keuangan yang kurang baik hal ini terlihat dari sejumlah kepalaDesadiKabupatenDompukebingungan untuk mengelola keuangan Desa sesuai yang diharapkan. Tentu ini dibuktikan dari 72 Desa yang ada di Kabupaten Dompu 38 diantaranya lulusan SMP sederajat, 25 lulusan SMA Sederajat dan 9 orang yang hanya lulusan sarjana S1. Sedangkan pada aspek sumber daya manusia, terdapat potensi persoalanberupatenagapendampingyang berpotensi melakukan korupsi dengan memanfaatkan lemahnya pengetahuan aparat desa. Hal ini berkaca pada program sejenis sebelumnya, PNPM Perdesaan, di manatenagapendampingyangseharusnya berfungsi membantu masyarakat dan aparat desa justru melakukan korupsi dan kecurangan. ${ }^{37}$

\section{Aspek regulasi dan lembaga}

Bapak M. Yusuf H. Abakar selaku kepala Desa Soriutu: Regulasi bisa dianggap masalah pada pengalokasian dana desa Kabupaten Dompu. Kurangnya pengetahuan perangkat desa tentang regulasi yang berlaku membuat pengalokasian tidak berjalan lancar. Setiap kali menerima dana, perangkat desa harus membuat surat pertanggungjawaban terlebih dahulu, padahal banyak perangkat desa yang tidak paham tentang proses ini serta belum lengkapnya regulasi dan petunjuk teknis pelaksanaan yang diperlukan dalam pengelolaan keuangan desa. Formula pembagian dana desa dalam PP No. 22 Tahun 2015 yang tidak cukup transparan dan hanya didasarkan atas pemerataan; hal ini sesuai dengan pembagian dana Desa yang berfarias dimasing-masing Desa yang ada di Kabupaten Dompu misalnya Desa Soriutu hanya mendapatkan dana sebesar 1.412.000.000 untuk anggaran 2016. Tentu ini tidak sesuai dengan yang digembar-

${ }^{37}$ Hasil wawancara dengan bapak H. Supardi, kepala BPMPD Kabupaten Dompu tanggal-4.Mei 2016. gemborkan selama ini, semua Desa yang ada di Indonesia akan memperoleh dana sebesar 1,4 milyar secara merata selain itu kewajiban penyusunan laporan pertanggung-jawaban oleh desa tidak efisien akibatnya masyarakat banyak bertanya tentang apa yang sudah dilakukan oleh kepala Desa dengan anggaran yang ada. ${ }^{38}$

3. Aspek tata laksana

Adapun wawancara dengan bapak Muhamad Ridwan,S.Ip:

a. Kerangka waktu siklus pengelolaan anggarandesasulitdipatuhiolehdesadi Kabupaten Dompu yang dimana salah satunya kepala desa Soriutu untuk anggaran Desa diperuntukkan tahun 2015 masih belum terpakai karena rencana prioritas pembangunan Desa sebagaidilaksanakandan sisa anggaran belum digunakan akan dilanjutkan untuk tahun 20016.

b. Satuan harga baku barang/jasa yang dijadikan acuan bagi desa dalam menyusun APBDes belum tersedia, acuan harga barang dan jasa sebagai bukti belanja pemerintah Desa dalam pelaksanaan pembangunan sangat diperlukan mengingat bahwa penggunaan anggaran untuk pembanguann dapat dipertanggungjawabkan melalui kwitansi harga acuan pemrintah Desa. Tentu ini dilakukan tidak lain agar tidak terjadi penympangan dalam penggunaan anggaran.

c. Transparansi rencana penggunaan dan pertanggung jawaban APBDes masih rendah tentu hal ini terlihat di lapangan bahwa sebagian besar masyarakatsetempattidak mengetahui jumlah dana yang diperoleh Desa karena kebiasaan kepala desa dalam rencana pembangunan dan

${ }^{38}$ Hasil wawancara dengan bapak M. Yusuf H. Abakar selaku kepala Desa Soriutu Kecamatan Manggelewa Kabupaten Dompu tanggal-12 Mei 2016. 
Sahrul Haidin| Pelaksanaan Pengelolaan Keuangan Desa Setelah Berlakunya Undang-Undang Nomor.....

pertanggungjawaban keuangan Desa hanya memberikan informasikan pada kelompok masyarakat tertentu dan tidak di informasikan kepada masyarakat secara keseluruhan.

d. Laporan pertanggungjawaban yang dibuat desa belum mengikuti standar dan rawan manipulasi, salah satunya disebabkan karena ketidakjelasan sistem akuntansi yang akan dipakai serta APBDes yang disusun tidak sepenuhnya menggambarkan kebutuhan yang diperlukan desa karena penyusunan tidak dilakukan secara partisipatif. $^{39}$

4. Kurangnya pengawasan

Wawancara dengan bapak Juliansyah ketua BPD:

a. Tidak efektivitas BPMD dan inspektorat daerah Kabupaten Dompu dalam melakukan pengawasan terhadap pengelolaan keuangan di desa masih rendah, tentu hal akan terlihat pada saat masyarakat melaporkan adanya penyimpangan penggunaan keuangan dalam pelaksanaan pembangunan yang dilakukan oleh kepala Desa setempat tidak ditanggapi serius oleh BPMD dan inspektorat daerah Kabupaten Dompu. Salah satu kasus yang melibatkan kepala Desa Tekasire sampai saat ini belum ada titik terang penyelesaianya pada hal kepala Desa tersebut selama menjabat sebagai kepala Desa pembangunan infrastruktur desa tidak berjalan dengan baik atau dengan kata lain dana desa tersebut tidak dapat dipertanggungjawabkan dalam penggunaannya di lapangan.

b. Saluran pengaduan masyarakat tidak dikelola dengan baik oleh pemerintah daerah Kabupaten Dompu dan me-

${ }^{39}$ Hasil wawancara dengan bapak Muhamad Ridwan, bidang pemerintahan Kecamatan Woja Kabupaten Dompu tanggal-9 Mei 2016. kanisme pengaduannya masyarakat yang berkaitan dengan penyimpangan yang melibatkan aparatDesatidakjelas tentu terbukti sebagian masyarakat setempat kebingungan melaporkan permasalahan Desa. ${ }^{40}$

\section{Upaya Penguatan Dalam Pelaksanaan Pengelolaan Keuangan Pemerintah Desa Setelah Berlakunya Undang-Un- dang No 6 Tahun 2014 Tentang Desa Di Kabupaten Dompu.}

\section{a. Meningkatkan kompetensi kepala desa}

Kepala desa dan stafnya memegang peranan penting dalam pengelolaan keuangan desa karena dia merupakan pemegang kekuasaan pengelolaan keuangan desa. Upaya yang dilakukan oleh pemerintah untuk menjamin pengelolaan keuangan desa yang baik telah melakukan langkah dalam meningkatkan kemampuan dan kompetensi seluruh kepala desa Kabupaten Dompu mengadakan pendidikan dan pelatihan di bidang teknis manajemen pengelolaan keuangan Desa yang mendukung, terkait penyelenggaraan pengelolaan keuangan pemerintahan desa agar dana desa dapat dioptimalkan sebaik mungkin untuk peningkatan kesejahteraan masyarakat dengan tanpa mengorbankan kualitas pengelolaannya. Seiring dengan titik berat pembangunan yang semakin bertumpu kepada desa, seharusnyalah persyaratan untuk pencalonan kepala desa juga ditingkatkan kualifikasinya. Penjaringan calon kepala desa yang berkualitas sedikit banyak akan ditentukan oleh masyarakat desa itu sendiri.

Setiap masyarakat mendapatkan pemimpin yang pantas dia dapatkan. Jika dinamika dan tatanan masyarakat desa berkembang secara organis dan demokratis, maka akan muncul pemimpin, terkait

${ }^{40}$ Hasil wawancara dengan bapak Juliansyah selaku ketua BPD Desa Madaparama Kecamatan Woja Kabupaten Dompu tanggal-17 Mei 2016. 
dengan syarat pencalonan kepala desa yang cukup berpendidikan SMP diakui menjadi masalah di Kabupaten Dompu. Kurang lebih 38 kepala Desa lulusan SMP sederajat, 25 lulusan SMA sederajat dan 9 orang lulusan sarjana S1 dari jumlah keseluruhan 72 kepala desa di Kabupaten Dompu. Keterbatasan pendidikan tersebut membuat sebagian kepala Desa tidak dapat memahami manajemen penyelenggaraan pemerintahan desa dengan baik. Tentu seyogianya pemerintah membuat peraturan daerah yang mensyaratkan pendidikan minimal kepala desa adalah SMA atau lulusan Sarjana, namun hal itu terbentur oleh peraturan perundangan yang lebih tinggi. yakni Undang-Undang Desa dan Permendagri No. 112 tahun 2014

Adapun hasil wawancara dengan narasumber baik dari BPMD, Camat, Kepala Desa dan BPD yang ada Kabupaten Dompu yakni : Wawancara dengan bapak Sugeng, kepala bidang BPMPD Dompu: Kami selaku pemerintah terutama untuk menjamin penyelenggaraan pemerintah Desa yang ada di Kabupaten dengan baik telah menganjurkan pada pemerintah Kabupaten untuk meningkatkan kemampuan dan kompetensi seluruh kepala desa Kabupaten Dompu mengadakan pendidikan dan pelatihan yang mendukung, terkait penyelenggaraan pemerintahan Desa agar dapat dilaksanakan sebaik mungkin untuk peningkatan kesejahteraan masyarakat dengan tanpa mengorbankan kualitas pengelolaannya. ${ }^{41}$ Bapak Alwi selaku pegawai camat Manggelewa Kabupaten Dompu: Upaya untuk mewujudkan pengelolaan keuangan Desa yang transparan pada masyarakat Desa dalam meningkatkan pembangunan dan pemberdayaan masyarakat Desa Kabupaten Dompu sesuai yang di amanatkan oleh Undang-Undang Desa tersebut, diperlukan

${ }^{41}$ Hasil wawancara dengan bapak Sugeng, kepala bidang BPMPD Kabupaten Dompu tanggal-4.Mei 2016. persyaratan memadai untuk pencalonan kepala desa juga ditingkatkan kualifikasinya. ${ }^{42}$

Bapak Suryadin, S.Pd salah satu kepala Desa Madaprama Kecamatan Woja Kabupaten Dompu menuturkan Penjaringan calon kepala desa yang berkualitas sedikit banyak akan ditentukan oleh masyarakat desa itu sendiri. Tentu hal ini apabila dilakukan maka akan berdampak positif pada kualitas kerja pengelolaan keuangan pemerintah Desa. ${ }^{43}$ Bapak Irawan, salah satu BPD Desa Tekasire Kecamatan Manggelewa Kabupaten Dompu: Untuk mewujudkan kemampuan dalam hal pengelolaan keuangan Desa tentu kepala Desa sebagai penanggungjawab peneyelenggaraan pemerintah Desa sudah diadakan pelatihan untuk memahami dan mentaati Undang-Undang Desa agar dalam pelaksanaan keuangan dapat mencapai sasaran yang di inginkan yaitu meningkatkan pembanguan Desa yang berdaya saing dan pemberdayaan masyarakat Desa. ${ }^{44}$

\section{b. Pendamping desa}

Pelaksanaan pengelolaan keuangan Desa yang mencapai milyaran rupiah diperlukan pendamping desa dalam menentukan terjaminnya pengelolaan keuangan desa secara transparan, akuntabel, dan partisipatif. Pasal 128 ayat (2) PP No. 43 Tahun 2014 bahwa pendampingan masyarakat desa dilaksanakan oleh satuan kerja perangkat daerah (SKPD) kabupaten/kota dan dapat dibantu oleh tenaga pendamping profesional, kader pemberdayaan masyarakat desa, dan/atau pihak ketiga. Pasal 128 ayat 3 bahwa camat atau sebutan lain melakukan koordinasi pendampingan masyarakat desa di wilayahnya. Ini artinya, pendampingan

42 Hasil wawancara dengan bapak Alwi selaku bidang pemerintahan Kecamatan Manggelewa Kabupaten Dompu tanggal-9 Mei 2016.

${ }^{43}$ Hasil wawancara dengan bapak Suryadin, selaku kepala Desa Madaprama Kecamatan Woja Kabupaten Dompu tanggal-12 Mei 2016.

${ }^{44}$ Hasil wawancara dengan bapak Irawan, selaku anggota BPD Desa Tekasire Kabupaten Dompu tanggal-17 Mei 2016. 
Sahrul Haidin| Pelaksanaan Pengelolaan Keuangan Desa Setelah Berlakunya Undang-Undang Nomor.....

dapat dilakukan oleh berbagai pihak, mulai dari pemerintah, masyarakat, dan bahkan swasta.

Pendampingan oleh jajaran pemerintah dikoordinasikan oleh Kemendagri dan pendampingan oleh masyarakat dikoordinasikan Kemendes PDTT. Menarik untuk disoroti di sini adalah tugas pendampingan yang dilaksanakan oleh masyarakat. Pendamping desa merupakan aktor di tingkat masyarakat yang berperan penting dalam mengawal pengelolaan keuangan desa. $^{45}$

Permendes PDTT No. 3 Tahun 2015 tentang Pendampingan Desa telah mengatur dengan rinci mengenai pendamping desa ini, di antaranya tujuan pendampingan desa, ruang lingkup pendampingan desa, tugas pendamping desa, manajemen pendampingan desa, dan pendanaannya. Di dalamnya disebutkan bahwa tujuan pendampingan desa meliputi:

a) meningkatkan kapasitas, efektivitas dan akuntabilitas pemerintahan desa dan pembangunan Desa;

b) meningkatkan prakarsa, kesadaran dan partisipasi masyarakat Desa dalam pembangunan desa yang partisipatif;

c) meningkatkan sinergi program pembangunan Desa antar sektor; dan.

d) mengoptimalkan aset lokal Desa secara emansipatoris (Pasal 2 Permendes PDTT No. 3 Tahun 2015).

Adapun pendamping desa terdiri atas tenaga pendamping profesional (yang terdiri atas pendamping desa yang berkedudukan di kecamatan, pendamping teknis yang berkedudukan di kabupaten, dan tenaga ahli pemberdayaan masyarakat yang berkedudukan di pusat dan provinsi), kader pemberdayaan masyarakat desa

${ }^{45}$ Hasil wawancara dengan bapak Alwi selaku bidang pemerintahan Kecamatan Manggelewa Kabupaten Dompu tanggal-9 Mei 2016. yang berkedudukan di desa dan diperoleh melalui mekanisme musyawarah desa, dan pihak ketiga (terdiri dari LSM, perguruan tinggi, organisasi masyarakat, dan perusahaan). Pendamping desa profesional memiliki tugas dalam ruang lingkup yang luas, di mana fasilitasi dan bimbingan pengelolaan keuangan Desa.

Adapun hasil wawancara dengan lima secara keseluruhan sebagai narasumber baik dari BPMPD, Camat, Kepala Desa dan BPD yang ada Kabupaten Dompu antara lain adalah: Bapak Sugeng kepala bidang BPMD Kabupaten Dompu Dengan mengutarakan : Adanya pendampingan Desa yang dilakukan oleh jajaran pemerintah dikoordinasikan oleh Kemendagri dan pendampingan oleh masyarakat dikoordinasikan Kemendes PDTT. Menarik untuk disoroti di sini adalah tugas pendampingan yang dilaksanakan oleh masyarakat. ${ }^{46}$ Bapak Alwi selaku bidang pemerintahan Kecamatan Manggelewa Kabupaten Dompu menjelaskan:Pendamping desa ini merupakan aktor di tingkat masyarakat yang berperan penting dalam mengawal penyelenggaraan pemerintah Desa yang berkaitan dengan pengelolaan keuangan yang baik dalam rangka meningkatkan pelaksanaan pembangunann dan pemberdayaan masyasrakat Desa. ${ }^{47}$

Bapak Suryadin, selaku kepala Desa Madaprama Kecamatan Woja Kabupaten Dompu:: Pendampingan Desa dalam pelaksanaan pengelolaan keuangan Desa di Kabupaten Dompu ,baik dari masyarakat maupun dari pemerintah itu sendiri sudah tentu melakukan fasilitasi untuk pemerintah dan masyarakat desa agar kegiatan pemerintahan Desa, pembangunan dan pemberdayaan masyarakat Desa dapat berjalan dengan efektif demi percepatan peningkatan kesejahteraan masyarakat

\footnotetext{
${ }^{46}$ Hasil wawancara dengan bapak Sugeng kepala bidang BPMPD Kabupaten Dompu tanggal-4.Mei 2016.

${ }^{47}$ Hasil wawancara dengan bapaki selaku bidang pemerintahan Kecamatan Manggelewa Kabupaten Dompu tanggal-9 Mei 2016.
} 
desa setempat. ${ }^{48}$ Bapak Irawan, selaku anggota BPD Desa Tekasire Kabupaten Dompu : Salah satu upaya dilakukan oleh pemerintah Kabupaten Dompu melalui BPMD Dompu mendapingi dimasingmasing Desa yang ada di Kabupaten Dompu Tentu ini dilakukan untuk mengefektifkan pengelolaan keuangan Desa demi tercapainya meningkatkan pembangunan dan pemberdayaan masyarakat Desa yang baik. $^{49}$

\section{SIMPULAN}

1. Pengaturan pengelolaan keuanga desa terdapatdalamUUNo6tahun2014tentang Desa, Pasal 1 angka 10, Pasal 71 Ayat (2). PP No 47 tahun 2015 Tentang perubahan atasPPNo43tahun2014tentangperaturan pelaksanaan UU No 6 tahun 2014 tentang desa Pasal 1 ayat 8 dan pasal 1 ayat 9 . KeuanganDesayangdiaturdalamUUDesa maupun peraturan lain belum mengatur secarajelas yangberkaitan denganstandar kwitansi pembelianbarang danjasa untuk Desa

2. Hambatan pelaksanaan pengelolaan keuangan desa : disebabkan rendahnya pendidikankepalaDesa,regulasimembuat surat pertanggungjawaban yang rumit, satuan harga material acuan bagi desa dalam menyusun APBDes belum tersedia dan transparansi rencana penggunaan dan pertanggung jawaban APBDes masih rendah dan LPJ yang dibuat desa belum mengikuti standar dan rawan manipulasi. dan kurangnya pengawasan, yakni tidak efektivitas BPMD dan inspektorat daerah.

3. Upaya penguatan dalam pelaksanaan pengelolaan keuangan pemerintah desa setelah berlakunya undang-undang no 6 tahun 2014 tentang antara lain:

${ }^{48}$ Hasil wawancara dengan bapak Suryadin, selaku kepala Desa Madaprama Kecamatan Woja Kabupaten Dompu tanggal-12 Mei 2016.

${ }^{49}$ Hasil wawancara dengan bapak Irawan, selaku anggota BPD Desa Tekasire Kabupaten Dompu tanggal-17 Mei 2016. a. Meningkatkan pengetahuan kepala desa mengadakan pendidikan dan pelatihan yang mendukung pelaksanaan tugas terkait penyelenggaraan pengelolaan keuangan pemerintahan desa.

b. Diberikan pendamping desa merupakan salah satu upaya untuk mengarahka kepala Desa dalam menentukan terjaminnya pengelolaan keuangan desa secara transparan, akuntabel, dan partisipatif.

\section{DAFTAR PUSTAKA}

\section{Buku}

Anthonius Sitepu,2012, Teori Politik, Graha Ilmu, Yogyakarta.

Cristine, C.S.T Kansil, 2003, Hukum Tata Negara Republik Indonesia, Rineka Cipta, Jakarta.

Himawan Estu Bagijo, 2014, Negara Hukum Dan Mahkamah Konstitusi Perwujudan Negara Hukum Yang Demokratis Melalui Wewenang Mahkamah Konstitusi Dalam Pengujian Undang-Undang, Laksbang Grafika, Yogyakarta.

Nanang Nugraha, 2013, Model Kewenangan Wakil Kepala Daerah Dalam Pemerintahan Daerah, Refika Aditama Bandung.

Ridwan H.R, 2006 Hukum Administrasi Negara, Raja Grafindo Persada, Jakarta.

Soetardjo, Yulianti, 2001 Interaksi DesaKota dan Permasalahannya, Ghalia Indonesia, Jakarta,

Salim HS dan Septiana Nurbani, Erlies, 2013, Penerapan Teori Hukum Pada Penelitian Tesis dan Disertasi, Raja Grafindo Persada Jakarta.

Salim Hs dan Erlies Setiana Nurbani, 2015, Penerapan Teori Hukum Pada Penelitian Desertasi dan Tesis, 
Sahrul Haidin| Pelaksanaan Pengelolaan Keuangan Desa Setelah Berlakunya Undang-Undang Nomor.....

Penerbit RajaGrafindo Persada Jakarta.

Widjaja, 2012, Otonomi Desa Merupakan Otonomi Yang Asli, Bulat Dan Utuh, Raja Grafindo Persada, Jakarta.

\section{B. Peraturan Perndang-Undangan}

Undang-Undang Dasar Negara Republik Indonesia Tahun 1945 Setelah Amandemen.

Undang-Undang Republik Indonesia No.

6 Tahun 2014 Tentang Desa. Penerbit Sinar Garafika Jakarta.

Undang-Undang Republik Indonesia No 30 tahun 14 Tentang Administrasi Pemerintahan

Peraturan Pemerintah Republik Indonesia Nomor 60 Tahun 2014 tentang Dana Desa.

Peraturan Pemerintah Republik Indonesia Nomor 47 Tahun 2017 tentang Perubahan Atas Peraturan Pemerintah Nomor 43 Tahun 2014 Tentang Peraturan Pelaksana Undang-Undang Nomor 6 Tahun 2014 Tentang Desa.

Peraturan Menteri Desa, Pembangunan Daerah Tertinggal, dan Transmigrasi Nomor 5 tahun 2015 Tentang Penetapan Prioritas Penggunaan dana Desa.

Peraturan Dalam Negeri Republik Indonesia Nomor 113 Tahun 2014 Tentang Pengelolaan Keuangan Desa.

Peraturan Mentri Keuangan Republik Indonesia Nomor 93 Tahun 2015 Tentang Tata Cara Pengalokasian, Penyaluran, Penggunaan, Pemantauan Dan Evaluasi Dana Desa

\section{Jurnal}

\begin{tabular}{ccc} 
Prawira, I. Gusti Bagus & Yoga. \\
"RESPONSIBILITY & OF & THE \\
CONVEYANCER & \multicolumn{2}{c}{ AGAINST }
\end{tabular}

SELLING LAND DEED.” Jurnal IUS (Kajian Hukum dan Keadilan) 4.1 (2016).

Supriadi, E. (2015). Pertanggungjawaban Kepala Desa Dalam Pengelolaan Keuangan Desa Berdasarkan Undang-Undang No 6 Tahun 2014 Tentang Desa. Jurnal IUS Kajian Hukum dan Keadilan Vol 3 No 8, 4. 